\title{
EKOSISTEM PADANG LAMUN (Manfaat, Fungsi dan Rehabilitasi)
}

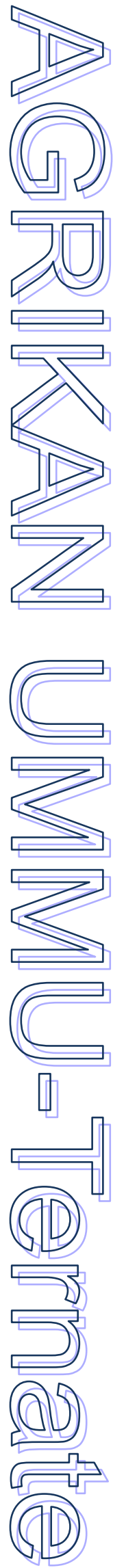

\author{
Umar Tangke \\ Staf Pengajar Faperta UMMU-Ternate, e-mail: khakafart@yahoo.com
}

\begin{abstract}
ABSTRAK
Ekosistem pesisir umumnya terdiri atas 3 komponen penyusun yaitu lamun, terumbu karang serta mangrove. Bersama-sama ketiga ekosistem tersebut membuat wilayah pesisir menjadi daerah yang relatif sangat subur dan produktif. Komunitas Lamun sangat berperan penting pada fungsi-fungsi biologis dan fisik dari lingkungan pesisir. Pola zonasi padang lamun adalah gambaran yang berupa rangkaian/model lingkungan dengan dasar kondisi ekologis yang sama pada padang lamun. Aktivitas manusia di sekitar pesisir dapat berupa pertanian, peternakan dan pelabuhan tradisional serta pemukiman penduduk. Oleh karena aktivitas manusia yang tidak memperhatikan lingkungan pesisir akan mengakibatkan perubahan komunitas lamun sebagai penunjang ekosistem pesisir. Banyak kegiatan pembangunan di wilayah pesisir telah mengorbankan ekosistem padang lamun, seperti kegiatan reklamasi untuk pembangunan kawasan industri atau pelabuhan ternyata menurut data yang diperoleh telah terjadi pengurangan terhadap luasan kawasan padang lamun, Sehingga pertumbuhan, produksi ataupun biomasanya akan mengalami penyusutan. Di sisi lain masih kurang upaya yang kita berikan untuk menyelamatkan ekosistem ini. Meskipun data mengenai kerusakan ekosistem padang lamun tidak tersedia tetapi faktanya sudah banyak mengalami degradasi akibat aktivitas di darat. Sebagai sumber daya pesisir, ekosistem padang lamun memiliki multi fungsi untuk menunjang sistem kehidupan dan berperan penting dalam dinamika pesisir dan laut, terutama perikanan pantai sehingga pemeliharaan dan rehabilitasi ekosistem lamun merupakan salah satu alasan untuk tetap mempertahankan keberadaan ekosistem tersebut.
\end{abstract}

\section{Kata Kunci: Lamun, Seagrass, Rehabilitasi}

\section{PENDAHULUAN}

\subsection{Latar Belakang}

Lamun (seagrass) adalah

tumbuhan berbunga (Angiospermae) yang dapat tumbuh dengan baik pada lingkungan laut dangkal (Wood et al. 1969). Semua lamun adalah tumbuhan berbiji satu (monokotil) yang mempunyai akar, rimpang (rhizoma), daun, bunga dan buah seperti halnya dengan tumbuhan berpembuluh yang tumbuh di darat (Tomlinson, 1974). Lamun senantiasa membentuk hamparan permadani di laut yang dapat terdiri dari satu species (monospesific; banyak terdapat di daerah temperate) atau lebih dari satu species (multispecific; banyak terdapat di daerah tropis) yang selanjutnya disebut padang lamun. Menurut Sheppard et al (1996), 
Ekosistem padang lamun merupakan ekosistem pesisir yang ditumbuhi oleh lamun sebagai vegetasi yang dominan serta mampu hidup secara permanen di bawah permukaan air laut.

Ekosistem padang lamun merupakan suatu ekosistem yang kompleks dan mempunyai fungsi dan manfaat yang sangat panting bagi perairan wilayah pesisir. Secara taksonomi lamun (seagrass) termasuk dalam kelompok Angiospermae yang hidupnya terbatas di lingkungan laut yang umumnya hidup di perairan dangkal wilayah pesisir. Distribusi lamun sangatlah luas, dari daerah perairan dangkal Selandia baru sampai ke Afrika. Dari 12 genera yang telah dikenal, 7 genera diantaranya berada dan tersebar di wilayah tropis (Den Hartog, 1970). Diversitas tertinggi ialah di daerah Indo Pasifik Barat. Komunitas lamun di wilayah ini mempunyai diversitas yang lebih kompleks dibanding yang berada di daerah sedang (Poiner \& Robert., 1986).

Ekosistem pesisir umumnya terdiri atas 3 komponen penyusun yaitu lamun, terumbu karang serta mangrove. Bersama-sama ketiga ekosistem tersebut membuat wilayah pesisir menjadi daerah yang relatif sangat subur dan produktif. Komunitas Lamun sangat berperan penting pada fungsi-fungsi biologis dan fisik dari lingkungan pesisir. Pola zonasi padang lamun adalah gambaran yang berupa rangkaian/model lingkungan dengan dasar kondisi ekologis yang sama pada padang lamun. Aktivitas manusia di sekitar pesisir dapat berupa pertanian, peternakan dan pelabuhan tradisional serta pemukiman penduduk. Aktivitas manusia yang tidak memperhatikan lingkungan pesisir akan mengakibatkan perubahan komunitas lamun sebagai penunjang ekosistem pesisir.

McRoy \& Hefferich (1977) menyatakan bahwa, padang lamun di daerah tropis merupakan ekosistem alam yang paling produktif. Data yang pernah diperoleh, produktifitasnya bisa sampai 1.300 sampai dengan 3000 gr berat kering $/ \mathrm{m}^{2} /$ tahun (Zieman 1975). Selain produktifitasnya yang tinggi, lamun juga mempunyai kecepatan pertumbuhan yang tinggi (Wood, et al., 1969).

Suatu yang sangat ironis jika kita perhatikan fungsi lamun yang begitu penting tetapi di sisi lain perhatian kita terhadap ekosistem ini sangat kurang . Kita melihat dua hal mendasar, 1) sebaran dan luasan ekosistem padang lamun di Indonesia; serta 2) tingkat kerusakan ekosistem padang lamun di Indonesia. Jawaban yang kita dapatkan adalah sebaran secara kualitatif, tapi luasan tidak pernah kita dapatkan. Adapun jawaban yang kedua jangan harap akan ada penjelasan untuk skop nasional.

Pertumbuhan dan kepadatan lamun sangat dipengaruhi oleh pola pasang surut, turbiditas, salinitas dan temperatur perairan. Kegiatan manusia di wilayah pesisir seperti perikanan, pembangunan perumahan, pelabuhan dan rekreasi, baik langsung maupun tidak langsung juga dapat mempengaruhi eksistensi lamun. Fauna yang berasosiasi dengan lamun biasanya sensitif oleh adanya siltasi dan rendahnya kadar oksigen terlarut akibat tingginya BOD di daerah lamun. Oleh karena itu segala bentuk perubahan di wilayah pesisir akibat aktivitas manusia yang tidak terkontrol dapat menimbulkan gangguan fungsi sistem ekologi padang lamun. Fenomena ini akan berpengaruh terhadap hilangnya unsur lingkungan seperti daerah pemijahan, nursery ground bagi ikan maupun udang.

Banyak kegiatan pembangunan di wilayah pesisir telah mengorbankan ekosistem padang lamun, seperti kegiatan reklamasi untuk pembangunan kawasan industri atau pelabuhan ternyata menurut data yang diperoleh telah terjadi pengurangan terhadap luasan kawasan padang lamun, Sehingga pertumbuhan, produksi ataupun biomasanya akan mengalami penyusutan. Di sisi lain masih kurang upaya yang kita 
berikan untuk menyelamatkan ekosistem ini. Meskipun data mengenai kerusakan ekosistem padang lamun tidak tersedia tetapi faktanya sudah banyak mengalami degradasi akibat aktivitas di darat.

Dampak nyata dari degradasi padang lamun mengarah pada menurnnya keragaman biota laut sebagai akibat hilang atau menurunnya fungsi ekologi dari ekosistem ini. Upaya rehabilitasi menjadi isu yang penting untuk dipikirkan bersama, seperti kegiatan transplantasi lamun pada suatu habitat yang telah rusak dan penanaman lamun buatan untuk menjaga kestabilan dan mempertahankan produktivitas perairan.

\section{BIO-EKOLOGI LAMUN}

\subsection{Klasifikasi}

Lamun menghasilkan buah dan menyebarkan bibit seperti banyak tumbuhan darat. Khusus untuk genera di daerah tropis memiliki morfologi yang berbeda sehingga pembedaan spesies dapat dilakukan dengan dasar gambaran morfologi dan anatomi. Lamun merupakan tumbuhan laut yang secara utuh memiliki perkembangan sistem perakaran dan rhizoma yang baik. Pada sistem klasifikasi, lamun berada pada Sub kelas Monocotyledoneae, kelas Angiospermae. Dari 4 famili lamun yang diketahui, 2 berada di perairan Indonesia yaitu Hydrocharitaceae dan Cymodoceae. Famili Hydrocharitaceae dominan merupakan lamun yang tumbuh di air tawar sedangkan 3 famili lain merupakan lamun yang tumbuh di laut.

Lamun merupakan tumbuhan yang beradaptasi penuh untuk dapat hidup pada lingkungan laut. Eksistensi lamun di laut merupakan hasil dari beberapa adaptasi yang dilakukan termasuk toleransi terhadap kadar garam yang tinggi, kemampuan untuk menancapkan akar di substrat sebagai jangkar, dan juga untuk tumbuh dan melakukan reproduksi pada saat terbenam. Lamun juga tidak memiliki stomata, mempertahankan kutikel yang tipis, perkembangan shrizogenous pada sistem lakunar dan keberadaan diafragma pada sistem lakunar.

Salah satu hal yang paling penting dalam adaptasi reproduksi lamun adalah hidrophilus yakni kemampuannya untuk melakukan polinasi di bawah air.

Secara rinci klasifikasi lamun menurut den Hartog (1970) dan Menez, Phillips,

dan Calumpong (1983) adalah sebagai berikut :

Divisi : Anthophyta

Kelas : Angiospermae

Famili : Potamogetonacea

Subfamili : Zosteroideae

Genus : Zostera

Phyllospadix

Heterozostera

Subfamili : Posidonioideae

Genus : Posidonia

Subfamili : Cymodoceoideae

Genus : Halodule

Cymodoceae

Syringodium

Amphibolis

Thalassodendron

Famili : Hydrocharitaceae

Subfamili : Hydrocharitaceae

\subsection{Habitat}

Lamun hidup dan terdapat pada daerah mid-intertidal sampai kedalaman 0,5-10 m, dan sangat melimpah di daerah sublitoral. Jumlah spesies lebih banyak terdapat di daerah tropik dari pada di daerah ugahari (Barber, 1985). Habitat lamun dapat dilihat sebagai suatu komunitas, dalam hal ini suatu padang lamun merupakan kerangka struktur dengan tumbuhan dan hewan yang saling berhubungan. Habitat lamun dapat juga dilihat sabagai suatu ekosistem, dalam hal ini hubungan hewan dan tumbuhan tadi dilihat sebagai suatu proses yang dikendalikan oleh pengaruh-pengaruh interaktif dari faktor-faktor biologis, fisika, kimiawi. Ekosistem padang lamun pada daerah tropik dapat menempati berbagai 
habitat, dalam hal ini status nutrien yang diperlukan sangat berpengaruh. Lamun dapat hidup mulai dari rendah nutrien dan melimpah pada habitat yang tinggi nutrien.

Lamun pada umumnya dianggap sebagai kelompok tumbuhan yang homogen. Lamun terlihat mempunyai kaitan dengan habitat dimana banyak lamun (Thalassia) adalah substrat dasar dengan pasir kasar. Menurut Haruna (Sangaji, 1994) juga mendapatkan Enhalus acoroides dominan hidup pada substrat dasar berpasir dan pasir sedikit berlumpur dan kadang-kadang terdapat pada dasar yang terdiri atas campuran pecahan karang yang telah mati.

\subsection{Karakteristik Vegetatif}

Bentuk vegetatif lamun dapat memperlihatkan karakter tingkat keseragaman yang tinggi dimana Hampir semua genera memiliki rhizoma yang berkembang dengan baik serta bentuk daun yang memanjang (linear) atau berbentuk sangat panjang seperti ikat pinggang (belt), kecuali jenis Halophila memiliki bentuk lonjong.

Berbagai bentuk pertumbuhan tersebut mempunyai kaitan dengan perbedaan ekologi lamun (den Hartog, 1977). Misalnya Parvozosterid dan Halophilid dapat dijumpai pada hampir semua habitat, mulai dari pasir yang kasar sampai lumpur yang lunak, dari daerah dangkal sampai dalam, dari laut terbuka sampai estuari. Magnosterid juga dijumpai pada berbagai substrat, tetapi terbatas pada daerah sublitoral sampai batas rata-rata daerah surut. Secara umum lamun memiliki bentuk luar yang sama, dan yang membedakan antar spesies adalah keanekaragaman bentuk organ vegetatif. Berbeda dengan rumput laut (marine alga/seaweeds), lamun memiliki akar sejati, daun, pembuluh internal yang merupakan sistem yang menyalurkan nutrien, air, dan gas.
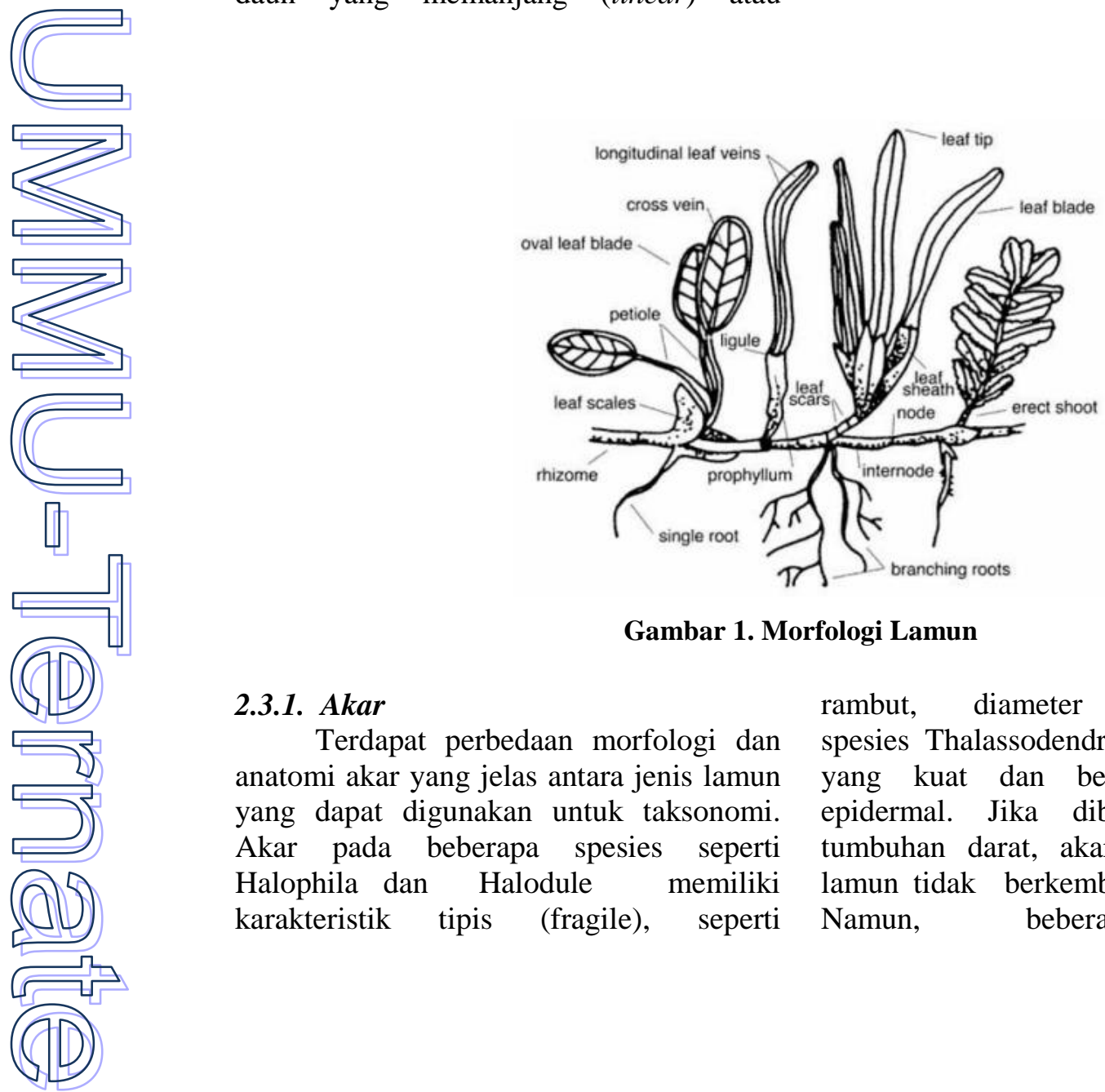

Gambar 1. Morfologi Lamun

\subsubsection{Akar}

Terdapat perbedaan morfologi dan anatomi akar yang jelas antara jenis lamun yang dapat digunakan untuk taksonomi. Akar pada beberapa spesies seperti Halophila dan Halodule memiliki karakteristik tipis (fragile), seperti rambut, diameter kecil, sedangkan spesies Thalassodendron memiliki akar yang kuat dan berkayu dengan sel epidermal. Jika dibandingkan dengan tumbuhan darat, akar dan akar rambut lamun tidak berkembang dengan baik. Namun, beberapa penelitian 
memperlihatkan bahwa akar dan rhizoma lamun memiliki fungsi yang sama dengan tumbuhan darat.

Akar-akar halus yang tumbuh di bawah permukaan rhizoma, dan memiliki adaptasi khusus (contoh : aerenchyma, sel epidermal) terhadap lingkungan perairan. Semua akar memiliki pusat stele yang dikelilingi oleh endodermis. Stele mengandung phloem (jaringan transport nutrien) dan xylem (jaringan yang menyalurkan air) yang sangat tipis. Karena akar lamun tidak berkembang baik untuk menyalurkan air maka dapat dikatakan bahwa lamun tidak berperan penting dalam penyaluran air. Patriquin (1972) menjelaskan bahwa lamun mampu untuk menyerap nutrien dari dalam substrat (interstitial) melalui sistem akar-rhizoma. Selanjutnya, fiksasi nitrogen yang dilakukan oleh bakteri heterotropik di dalam rhizosper Halophila ovalis, Enhalus acoroides, Syringodium isoetifolium dan Thalassia hemprichii cukup tinggi lebih dari $40 \mathrm{mg}$ N.m-2.day1. Koloni bakteri yang ditemukan di lamun memiliki peran yang penting dalam penyerapan nitrogen dan penyaluran nutrien oleh akar. Fiksasi nitrogen merupakan proses yang penting karena nitrogen merupakan unsur dasar yang penting dalam metabolisme untuk menyusun struktur komponen sel.

Diantara banyak fungsi, akar lamun merupakan tempat menyimpan oksigen untuk proses fotosintesis yang dialirkan dari lapisan epidermal daun melalui difusi sepanjang sistem lakunal (udara) yang berliku-liku. Sebagian besar oksigen yang disimpan di akar dan rhizoma digunakan untuk metabolisme dasar sel kortikal dan epidermis seperti yang dilakukan oleh mikroflora di rhizospher. Beberapa lamun diketahui mengeluarkan oksigen melalui akarnya (Halophila ovalis) sedangkan spesies lain (Thallassia testudinum) terlihat menjadi lebih baik pada kondisi anoksik. Larkum et al (1989) menekankan bahwa transport oksigen ke akar mengalami penurunan tergantung kebutuhan metabolisme sel epidermal akar dan mikroflora yang berasosiasi. Melalui sistem akar dan rhizoma, lamun dapat memodifikasi sedimen di sekitarnya melalui transpor oksigen dan kandungan kimia lain. Kondisi ini juga dapat menjelaskan jika lamun dapat memodifikasi sistem lakunal berdasarkan tingkat anoksia di sedimen. Dengan demikian pengeluaran oksigen ke sedimen merupakan fungsi dari detoksifikasi yang sama dengan yang dilakukan oleh tumbuhan darat. Kemampuan ini merupakan adaptasi untuk kondisi anoksik yang sering ditemukan pada substrat yang memiliki sedimen liat atau lumpur. Karena akar lamun merupakan tempat untuk melakukan metabolisme aktif (respirasi) maka konnsentrasi $\mathrm{CO} 2$ di jaringan akar relatif tinggi.

\subsubsection{Rhizoma dan Batang}

Semua lamun memiliki lebih atau kurang rhizoma yang utamanya adalah herbaceous, walaupun pada Thallasodendron ciliatum (percabangan simpodial) yang memiliki rhizoma berkayu yang memungkinkan spesies ini hidup pada habitat karang yang bervariasi dimana spesies lain tidak bisa hidup. Kemampuannya untuk tumbuh pada substrat yang keras menjadikan T. Ciliatum memiliki energi yang kuat dan dapat hidup berkoloni disepanjang hamparan terumbu karang di pantai selatan Bali, yang merupakan perairan yang terbuka terhadap laut Indian yang memiliki gelombang yang kuat.

Struktur rhizoma dan batang lamun memiliki variasi yang sangat tinggi tergantung dari susunan saluran di dalam stele. Rhizoma, bersama sama dengan akar, menancapkan tumbuhan ke dalam substrat. Rhizoma seringkali terbenam di dalam substrat yang dapat meluas secara ekstensif dan memiliki peran yang utama pada reproduksi secara vegetatif. Dan reproduksi yang dilakukan secara vegetatif merupakan 
hal yang lebih penting daripada reproduksi dengan pembibitan karena lebih menguntungkan untuk penyebaran lamun. Rhizoma merupakan 60-80\% biomas lamun.

\subsubsection{Daun}

Seperti semua tumbuhan monokotil, daun lamun diproduksi dari meristem basal yang terletak pada potongan rhizoma dan percabangannya. Meskipun memiliki bentuk umum yang hampir sama, spesies lamun memiliki morfologi khusus dan bentuk anatomi yang memiliki nilai taksonomi yang sangat tinggi. Beberapa bentuk morfologi sangat mudah terlihat yaitu bentuk daun, bentuk puncak daun, keberadaan atau ketiadaan ligula. Contohnya adalah puncak daun Cymodocea serrulata berbentuk lingkaran dan berserat, sedangkan C. Rotundata datar dan halus. Daun lamun terdiri dari dua bagian yang berbeda yaitu pelepah dan daun. Pelepah daun menutupi rhizoma yang baru tumbuh dan melindungi daun muda. Tetapi genus Halophila yang memiliki bentuk daun petiolate tidak memiliki pelepah.

Anatomi yang khas dari daun lamun adalah ketiadaan stomata dan keberadaan kutikel yang tipis. Kutikel daun yang tipis tidak dapat menahan pergerakan ion dan difusi karbon sehingga daun dapat menyerap nutrien langsung dari air laut. Air laut merupakan sumber bikarbonat bagi tumbuh-tumbuhan untuk penggunaan karbon inorganik dalam proses fotosintesis.

\subsection{Faktor Pembatas}

Faktor-faktor pembatas yang menjadi penghalang bagi pertumbuhan lamun adalah diantaranya dapat di lihat pada Tabel 1.

Tabel 1. Faktor-Faktor Pembatas Bagi Pertumbuhan Lamun

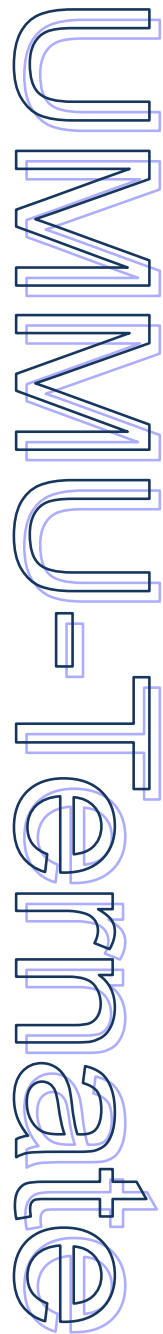

\begin{tabular}{cll}
\hline NO & FAKTOR PE MB AT AS & PENGARUH YANG OIBERIKAN \\
\hline 1 & Cahaya $(10-20 \%)$ & - Fotosintesis \\
& & - Mempengaruhi distribusi berdasarkan kedalaman \\
2 & Kedalaman & - Penetrasi cahaya \\
& & - Peningkatan tekanan hidrostatis \\
3 & Periode Pasut & - Ketersediaan cahaya \\
& & - Kekeringan jika lerekspos pada saing hari \\
4 & Arus dan Gelombang & - Distribusi spcsics - Proses reproduksi \\
5 & Salinitas & - Stress terhadap tekanan osmotik \\
6 & Suhu & - Suhu optimum untuk fotosintesis dan pertumbuhan \\
& & - Distribusi berbeda untuk lintang \\
7 & Anthropogems & - Eutrofikasi \\
& & - Sedimentasi \\
& & - Boat anchoring \\
& & - Dredging \\
& & - Polusi perairan \\
\hline
\end{tabular}

Sumber:

\section{FUNGSI DAN PERANAN}

\subsection{Fungsi Lamun}

Menurut Aswandy (2003) dalam penelitian mengenai Asosiasi Fauna Krustasea Dengan Potongan-Potongan Lamun Di Laut Dalam, menyatakan bahwa lamun dapat berfungsi sebagai :

\subsubsection{Substrat}

Substrat keras umumnya jarang ditemukan di perairan laut dalam, sehingga tidak begitu aneh bila lamun menjadi pilihan utama untuk dijadikan substrat oleh beberapa biota yang berasosiasi termasuk fauna krustasea. Hal ini 
didasarkan atas ditemukannya sejumlah bentuk yang berbeda dari cangkang fauna pada material lamun yang disampel. Beberapa organisme krustasea yang ditemukan, sebagian besar adalah bukan merupakan taxa utama. Pada bagian daun lamun ditemukan potongan-potongan kecil dari biota yang menempel pada lapisan substrat yang tebal. Lebih kurang 100 organisme dengan panjang antara 5-15 mm ditemukan pada material lamun. Dari hasil pengamatan, fauna krustasea yang teridentifikasi antara lain adalah:

1. Cirripedia; biota ini ditemukan pada rimpang lamun yang menyerupai sebuah tabung polikhaeta. Teridentifikasi bahwa pada satu teritip dengan panjang $5,2 \mathrm{~mm}$, ditemukan lebih dari 300 jenis yang termasuk marga Arcoscalpellum.

2. Tanaidacea; biota assosiasi ini ditemukan pada daun Thalassia dengan panjang spesimen 2-3 $\mathrm{mm}$. Biota ini termasuk famili Paratanaidae.

\subsubsection{Tempat berlindung}

Sejumlah spesimen dari Echinothambema ditemukan pada rizhome lamun, Biota tersebut menggunakan rhizome lamun hanya sebagai tempat berlindung. Kondisi ini juga ditemukan pada beberapa jenis biota dari Isopoda. Spesimen Isopoda ada yang ditemukan pada bagian dalam dan luar dari rhizoma Thalassia (WOLFF, 1975). Fauna krustasea yang menggunakan lamun sebagai tempat berlindung diantaranya adalah:

1. Isopoda; Dari 55 spesimen yang diteiiti dalam rhizome lamun tersebut ada sekitar 8-9 jenis Isopoda, biota ini mempunyai kelimpahan lebih tinggi di dalam rhizome lamun Thalassia. Jenis umum dari Isopoda yang teridentifikasi adalah dari jenis Echinothambema sp. dengan panjang 4$5 \mathrm{~mm}$ yang ditemukan sekitar $80 \%$ dalam rhizome dan $20 \%$ diluar rhizome. Kadang-kadang pada satu rhizome ditemukan jenis jantan dan betina. Pada beberapa spesimen teridentifikasi biota Katianira sp. dengan ukuran sekitar 3 $\mathrm{mm}$ pada rhizome Thalassia. Diduga pada spesimen tersebut juga ada genus Heteromesus yang termasuk suku Ischnomesidae pada beberapa material rhizome lamun dari Thalassia tersebut. Kemudian satu jenis baru dari marga Macrostylis yang panjangnya $3 \mathrm{~mm}$ juga ditemukan dalam rhizome dan jenis dari marga Haploniscus juga ditemukan pada sejumlah rhizome.

2. Amphipoda; Berdasarkan pengamatan ada satu jenis baru dari marga Onesimoides dari suku Lyasinassidae yang ditemukan pada bagian pangkal rhizome dan daun dari lamun Thalassia.

\subsubsection{Makanan}

Telah diketahui bahwa bahan organik merupakan sumber energi untuk beberapa fauna laut dalam (Wolff, 1962). Di sepanjang perairan Carolina ditemukan adanya hubungan antara konsentrasi detritus organik dari material Thalassia dengan distribusi dari beberapa biota pemakan suspensi (suspension feeders). Lebih lanjut dikatakan bahwa di perairan Puerto Rico dan Cayman di temukan fauna Amphipoda dari jenis Onesimoides sp. yang menggunakan Thalassia sebagai sumber makanan. Biasanya fauna ini ditemukan dalam potongan-potongan kayu yang didalamnya terdapat detritus lamun. Beberapa hasil penelitian menunjukkan bahwa lamun merupakan makanan dari fauna herbivorous di perairan laut dalam yang berdekatan dengan daerah padang lamun yang padat di daerah laut dangkal. Hal ini membuktikan bahwa walaupun tidak ada angin topan atau badai, potongan lamun dapat saja terbawa dan terjebak dilaut dalam. Biasanya daun, seludang atau rhizome dari lamun dijadikan makanan bagi fauna herbifora di laut dalam dalam waktu yang relatif lama, berdasarkan kondisi lingkungan yang 
biasanya menurun secara perlahan (Jannasch et al. 1971; Jannasch \& Wirsen, 1973).

$$
\text { Wolff (1975) mengemukakan }
$$

bahwa ada indikasi biota Isopoda memakan jenis lamun Thalassia. Hal ini berdasarkan material lamun yang berwarna coklat kekuning-kuningan yang diindikasikan sebagai jaringan lamun Thalassia. Pada material

tersebut ditemukan bagian mulut dari Krustasea bersama spikula dari sponge dan kista dari alga kuning. Pada material yang lebih lebar, ditemukan Echinothambema yang merupakan pemakan deposit (deposit feeder). Biota tersebut sangat selektif pada ukuran partikel dan kadang-kadang juga dapat berubah menjadi biota karnivora (Wolff, 1962).

\subsection{Fungsi Padang Lamun}

Padang lamun memiliki berbagai fungsi ekologi yang vital dalam ekosistem pesisir dan sangat menunjang dan mempertahankan biodiversitas pesisir dan lebih penting sebagai pendukung produktivitas perikanan pantai. Beberapa fungsi padang lamun, yaitu: 1) sebagai stabilisator perairan dengan fungsi sistem perakannya sebagai perangkap dan pengstabil sedimen dasar sehingga perairan menjadi lebih jernih; 2) lamun menjadi sumber makanan langsung berbagai biota laut (ikan dan non ikan); 3) lamun sebagai produser primer; 4) komunitas lamun memberikan habitat penting (tempat hidup) dan perlindungan (tempat berlindung) untuk sejumlah spesies hewan; dan 5) lamun memegang fungsi utama dalam daur zat hara dan elemenelemen langka di lingkungan laut (Phillips dan Menez, 1988; Fortes, 1990).

Dalam sistem rantai makanan khususnya pada daun-daun lamun yang berasosiasi dengan alga kecil yang dikenal dengan periphyton dan epiphytic dari detritus yang merupakan sumber makanan terpenting bagi hewan-hewan kecil seperti ikan-ikan kecil dan invertebrate kecil contohnya ; beberapa jenis udang, kuda laut, bivalve, gastropoda, dan Echinodermata. Lamun juga mempunyai hubungan ekologis dengan ikan melalui rantai makanan dari produksi biomasanya. Epiphyte ini dapat tumbuh sangat subur dengan melekat pada permukaan daun lamun dan sangat di senangi oleh udang-udang kecil dan beberapa jenis ikan-ikan kecil. Disamping itu padang lamun juga dapat melindungi hewan-hewan kecil tadi dari serangan predator. Selain itu, padang lamun diketahui mendukung berbagai jaringan rantai makanan, baik yang didasari oleh rantai herbivor maupun detrivor (Gambar 1). Perubahan rantai makanan ini bisa terjadi karena adanya perubahan yang cepat dari perkembangan perubahan makanan oleh predator,dan adanya perubahan musiman terhadap melimpahnya makanan untuk fauna.

Walaupun begitu, sejauh ini belum banyak diketahui bagaimana rantai energi dan nutrien tersebut selanjutnya berperan dalam ekosistem pesisir yang lebih luas (Gambar 2). Selain duyung, manate dan penyu, tidak banyak jenis ikan dan invertebrata yang diketahui memakan daun-daun lamun ini. Sehingga kemungkinan yang paling besar, lamun ini menyumbang ke dalam ekosistem pantai melalui detritus, yakni serpih-serpih bahan organik (daun, rimpang dll.) yang membusuk yang diangkut arus laut dan menjadi bahan makanan berbagai organisme pemakan detritus (dekomposer) (Nybakken, 1988). Dengan kata lain aliran energi di padang lamun itu sendiri terjadi karena adanya proses makan memakan baik itu secara langsung dari daun lamunnya terus di makan konsumen I maupun secara tidak langsung sebagai detritus dimakan oleh konsumen I dan seterusnya. Lamun yang mati akan kehilangan protein dan materi organik lain yang dimakan oleh fauna pada saat permulaan dekomposisi. Struktur karbohidrat diambil dari 
mikroflora (bakteri dan jamur). Banyak dari metozoa yang dapat mencerna protein bakteri dan serasah daun lamun diekskresi oleh fauna dan bentuk yang belum dicerna akan didekomposisi lagi oleh mikroba decomposer sehingga sumbar detritus akan meningkat.
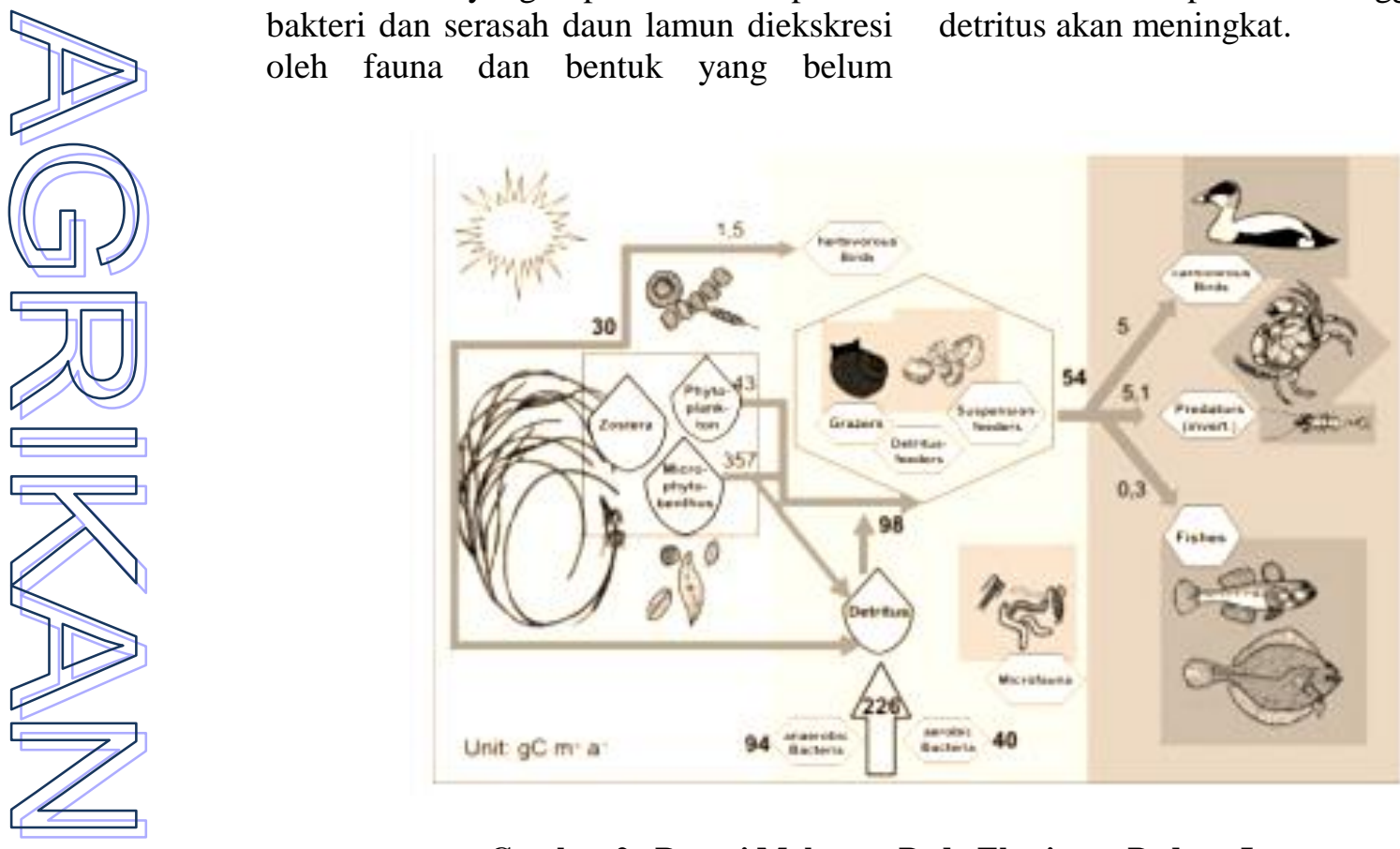

Gambar 2. Rantai Makanan Pada Ekosistem Padang Lamun (Sumber: www.krak.com/ query?stq=0\&what=wrel...lamun\% 2F)
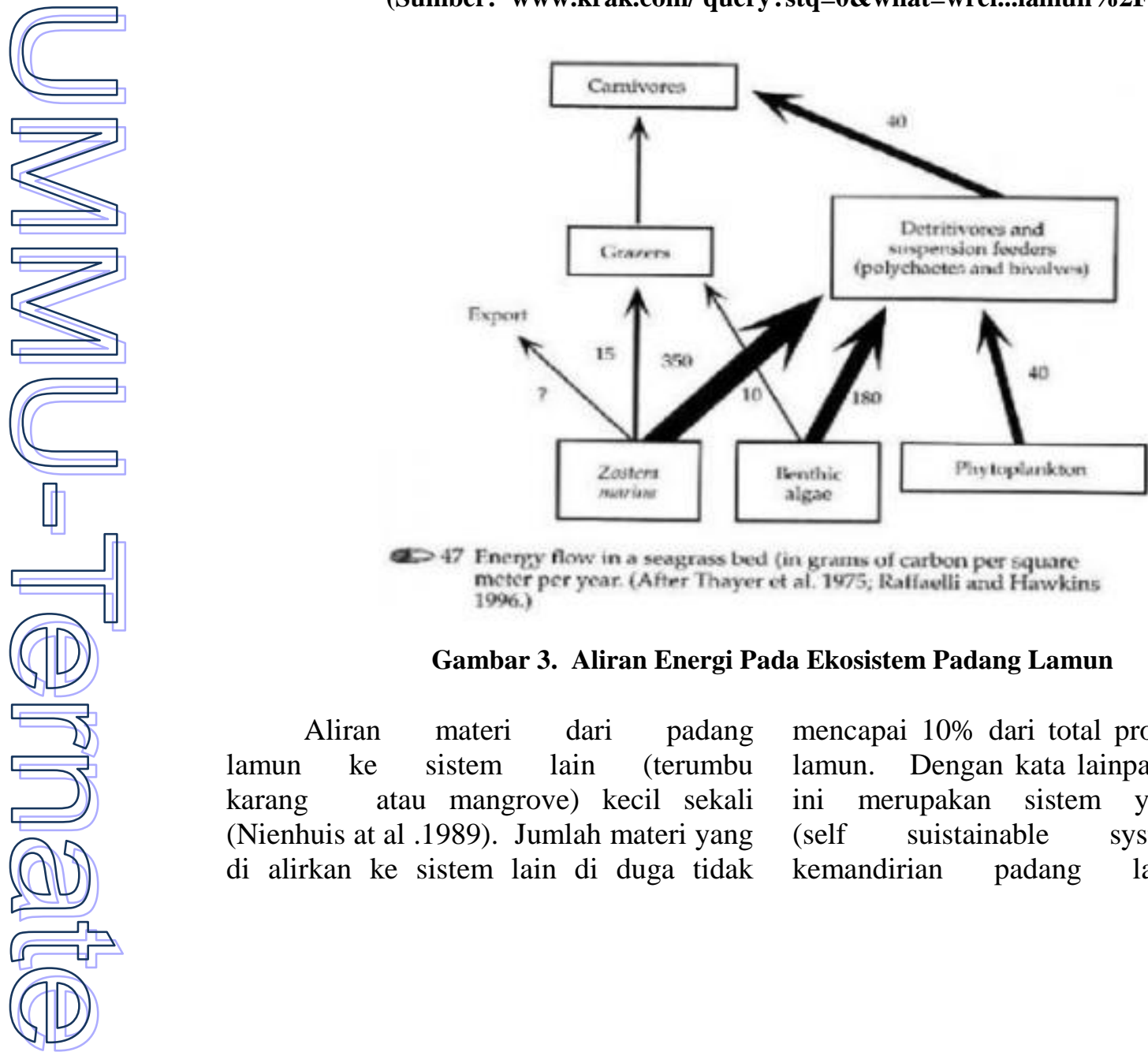

\begin{abstract}
47 Fnergy flow in a seagrass bed (in grams of carbon per square meter per year. (After Thayer et al. 1975; Raflavlli and Hawkins 1996.)
\end{abstract}

\title{
Gambar 3. Aliran Energi Pada Ekosistem Padang Lamun
}

Aliran materi dari padang mencapai $10 \%$ dari total produksi padang lamun ke sistem lain (terumbu lamun. Dengan kata lainpadang lamun karang atau mangrove) kecil sekali ini merupakan sistem yang mandiri (Nienhuis at al .1989). Jumlah materi yang (self suistainable system). Namun di alirkan ke sistem lain di duga tidak kemandirian padang lamun tidak 
meniadakan kehadiran dari kepentingan ratusan jenis-jenis hewan (Nontji, interaksi biotik dari ekosistem 1987; Hutomo \&

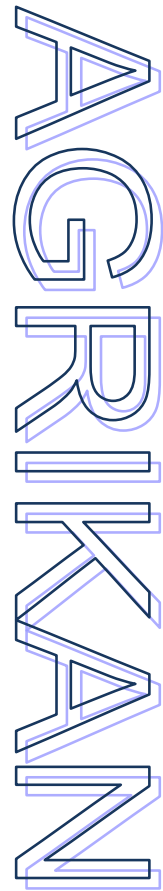
sekitarnya. Sistem dipadang lamun Martosewojo. 1977). diketahui sebagai suatu habitat untuk

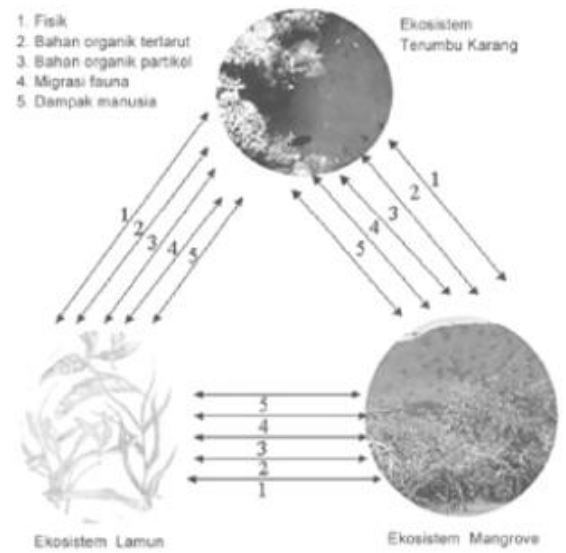

Gambar 4. Tipe interaksi antara ekosistem padang lamun dengan ekosistem mangrove dan terumbu karang (Ogden dan Gladfelter, 1983 dalam Bengen, 2001)

Posisi padang lamun tropis yang terletak diantara mangrove dan terumbu karang (Gambar 3) yang bertindak sebagai daerah penyangga yang baik, mengurangi energi gelombang dan mengalirkan nutrisi ke ekosistem terdekatnya. Tetapi interaksi ekosistem tersebut (mangrove, padang lamun dan terumbu karang) dalam hubungannya dengan degradasi penyangga adalah jelas keterkaitannya. Kerusakan dari salah satu ekosistem dapat menyebabkan akibat jelek pada ekosistem lainnya dalam hubungannya dengan perubahan-perubahan keseimbangan lingkungan dan

konsekwensinya akan merubah struktur komunitas keseluruhannya.

\subsection{Peranan Padang Lamun}

Dari hasil penelitian para peneliti diketahui bahwa peranan lamun di lingkungan perairan laut dangkal adalah sebagai berikut:

a. Sebagai Produsen Primer : Lamun mempunyai tingkat produktivitas primer tertinggi bila dibandingkan dengan ekosistem lainnya yang ada di laut dangkal seperti ekosistem mangrove dan ekosistem terumbu karang (Thayer et al 1975).

b. Sebagai Habitat Biota : Lamun memberikan tempat perlindungan dan tempat menempel berbagai hewan dan tumbuh-tumbuhan (algae). Disamping itu, padang lamun (seagrass beds) dapat juga sebagai daerah asuhan, padang pengembalaan dan makanan dari berbagai jenis ikan herbivora dan ikanikan karang (coral fishes) (Kikuchi \& Peres 1977).

c. Sebagai Penangkap Sedimen : Daun lamun yang lebat akan memperlambat air yang disebabkan oleh arus dan ombak, sehingga perairan disekitarnya menjadi tenang. Disamping itu, rimpang dan akar lamun dapat menahan dan mengikat sedimen, sehingga dapat menguatkan dan menstabilkan dasar permukaan. Jadi padang lamun yang berfungsi sebagai penangkap sedimen dapat mencegah erosi (Gingsburg \& Lowenstan 195 8, Thoraug \& Austin, 1976).

d. Sebagai Pendaur Zat Hara : Lamun memegang peranan penting dalam 
pendauran berbagai zat hara dan elemen-elemen yang langka di lingkungan laut. khususnya zat-zat hara yang dibutuhkan oleh algae epifitik.

\section{PEMANFAATAN ANCAMAN \\ PADANG LAMUN}

DAN

Philips \& Menez (1988) menytakan bahwa, lamun digunakan sebagai komoditi yang sudah banyak dimanfaatkan oleh masyarakat baik secara tradisional maupun secara modern. Secara tradisional lamun telah dimanfaatkan untuk :

1. Kompos dan pupuk

2. Cerutu dan mainan anak-anak

3. Dianyam menjadi keranjang

4. Tumpukan untuk pematang

5. Mengisi kasur

6. Ada yang dimakan

7. Dibuat jaring ikan

Pada zaman modern ini, lamun telah dimanfaatkan untuk :

1. Penyaring limbah

2. Stabilizator pantai

3. Bahan untuk pabrik kertas

4. Makanan

5. Obat-obatan

6. Sumber bahan kimia.

Lamun kadang-kadang membentuk suatu komunitas yang merupakan habitat bagi berbagai jenis hewan laut. Komunitas lamun ini juga dapat memperlambat gerakan air. bahkan ada jenis lamun yang dapat dikonsumsi bagi penduduk sekitar pantai. Keberadaan ekosistem padang lamun masih belum banyak dikenal baik pada kalangan akdemisi maupun masyarakat umum, jika dibandingkan dengan ekosistem lain seperti ekosistem terumnbu karang dan ekosistem mangrove, meskipun diantara ekosistem tersebut di kawasan pesisir merupakan satu kesatuan sistem dalam menjalankan fungsi ekologisnya

Keberadaaan lamun pada daerah mid-intertidal sampai kedalaman 0,5-10 m, dan juga terlihat mempunyai kaitan dengan habitat dimana banyak lamun (Thalassia) adalah substrat dasar dengan pasir kasar. Menurut Haruna (Sangaji, 1994) juga mendapatkan Enhalus acoroides dominan hidup pada substrat dasar berpasir dan pasir sedikit berlumpur dan kadang-kadang terdapat pada dasar yang terdiri atas campuran pecahan karang yang telah mati. Keberadaan lamun pada kondisi habitat tersebut, tidak terlepas dan ganguan atau ancaman-ancaman terhadap kelansungan hidupnya baik berupa ancaman alami maupun ancaman dari aktivitas manusia.

Banyak kegiatan atau proses, baik alami maupun oleh aktivitas manusia yang mengancam kelangsungan ekosistem lamun. Ekosistem lamun sudah banyak terancam termasuk di Indonesia baik secara alami maupun oleh aktifitas manusia. Besarnya pengaruh terhadap integritas sumberdaya, meskipun secara garis besar tidak diketahui, namun dapat dipandang di luar batas kesinambungan biologi. Perikanan laut yang meyediakan lebih dari $60 \%$ protein hewani yang dibutuhkan dalam menu makanan masyarakat pantai, sebagian tergantung pada ekosistem lamun untuk produktifitas dan pemeliharaanya. Selain itu kerusakan padang lamun oleh manusia

akibat pemarkiran perahu yang tidak terkontrol (Sangaji, 1994).

Ancaman-ancaman alami terhadap ekosistem lamun berupa angin topan, siklon (terutama di Philipina), gelombang pasang, kegiatan gunung berapi bawah laut, interaksi populasi dan komunitas (pemangsa dan persaingan), pergerakan sedimen dan kemungkinan hama dan penyakit, vertebrata pemangsa lamun seperti sapi laut. Diantara hewan invertebrata, bulu babi adalah pemakan lamun yang utama. Meskipun dampak dari pemakan ini hanya setempat, tetapi jika terjadi ledakan populasi pemakan tersebut akan terjadi kerusakan berat. Gerakan pasir juga mempengaruhi sebaran lamun. Bila air menjadi keruh karena sedimen, lamun akan bergeser ke 
tempat yang lebih dalam yang tidak memungkinkan untuk dapat bertahan hidup (Sangaji, 1994).

Limbah pertanian, industri, dan rumah tangga yang dibuang ke laut, pengerukan lumpur, lalu lintas perahu yang padat, dan lain-lain kegiatan manusia dapat mempunyai pengaruh yang merusak lamun. Di tempat hilangnya padang lamun, perubahan yang dapat diperkirakan menurut Fortes (1989), yaitu:

1. Reduksi detritus dari daun lamun sebagai konsekuensi perubahan dalam jaring-jaring makanan di daerah pantai dan komunitas ikan.

2. Perubahan dalam produsen primer yang dominan dari yang bersifat bentik yang bersifat planktonik.

3. Perubahan dalam morfologi pantai sebagai akibat hilangnya sifat-sifat pengikat lamun.

4. Hilangnya struktural dan biologi dan digantikan oleh pasir yang gundul.

Banyak kegiatan atau proses dari alam maupun aktivitas manusia yang mengancam kelangsungan hidup ekosistem lamun seperti Tabel 2.

Selain beberapa ancaman tersebut, kondisi lingkungan pertumbuhan juga mempengaruhi kelangsungan hidup suatu jenis lamun, seperti yang dinyatakan oleh Barber (1985) bahwa temperatur yang baik untuk mengontrol produktifitas lamun pada air adalah sekitar $20-30^{\circ} \mathrm{C}$ untuk jenis lamun Thalassia testudinum dan sekitar $30^{\circ} \mathrm{C}$ untuk Syringodium filiforme. Intensitas cahaya untuk laju fotosintesis lamun menunjukkan peningkatan dengan meningkatnya suhu dari $29-35^{\circ} \mathrm{C}$ untuk Zostera marina, $30^{\circ} \mathrm{C}$ untuk Cymidoceae nodosa dan 25 $30^{\circ} \mathrm{C}$ untuk Posidonia oceanica.

Kondisi ekosistem padang lamun di perarain pesisir Indonesia sekitar 30-40\%. Di pesisir pulau Jawa kondisi ekosistem padang lamun telah mengalami gangguan yang cukup serius akibat pembuangan limbah indusri dan pertumbuhan penduduk dan diperkirakan sebanyak $60 \%$ lamun telah mengalami kerusakan. Di pesisir pulau Bali dan pulau Lombok ganguan bersumber dari penggunaan potassium sianida dan telah berdampak pada penurunan nilai dan kerapatan sepsiens lamun (Fortes, 1989). Selanjutnya dijelaskan oleh Fortes (1989) bahwa rekolonialisasi ekosistem padang lamun dari kerusakan yang telah terjadi membutuhkan waktu antara 5 15 tahun dan biaya yang dibutuhkan dalam mengembalikan fungsi ekosistem padang lamun di daerah tropis berkisar 22800 - 684.000 US \$/ha. Oleh karena itu aktiviras pembangunan di wilayah pesisir hendaknya dapat memenimalkan dampak negatif melalui pengkajian yang mendalam pada tiga aspek yang tekait yaitu: aspek kelestarian lingkungan, aspek ekonomi dan aspek sosial.

Ancaman kerusakan ekosistem padang lamun di perairan pesisir berasal dari aktivitas masyarakat dalam mengeksploatasi sumberdaya ekosistem padang lamun dengan menggunakan potassium sianida, sabit dan gareng serta pembuangan limbah industri pengolahan ikan, sampah rumah tangga dan pasar tradisional. Dalam hal ini Fauzi (2000) menyatakan bahwa dalam menilai dampak dari suatu akifitas masyarakat terhadap kerusakan lingkungan seperti ekosistem padang lamun dapat digunakan dengan metode tehnik evaluasi ekonomi yang dikenal dengan istilah Environmental Impact Assesment (EIA). Metode ini telah dijadikam istrumen universal dalam mengevaluasi dampak lingkungan akibat aktivitas pembangunan, disamping itu metode evaluasi ekonomi dapat menjembatani kepentingan ekonomi masyarakat dan kebutuhan ekologi dari sumber daya alam. 
Tabel 2. Dampak Kegiatan Manusia Pada Ekosistem Padang Lamun (Bengen, 2001)

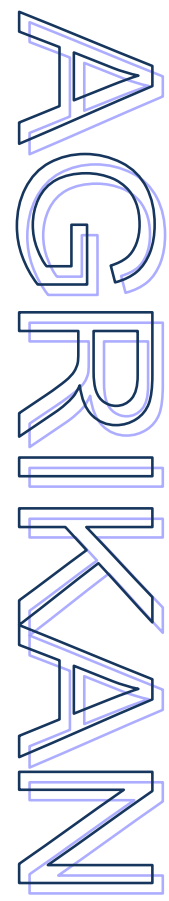

\begin{tabular}{|c|c|c|}
\hline NO & FAKTOR PEMBATAS & PENGARUH YANG DIBERIKAN \\
\hline 1 & Cahaya (10 - 20\%) & $\begin{array}{l}\text { - Fotosintesis } \\
\text { - Mempengaruhi distribusi berdasarkan } \\
\text { kedalaman }\end{array}$ \\
\hline 2 & Kedalaman & $\begin{array}{l}\text { - Penetrasi cahaya } \\
\text { - Peningkatan tekanan hidrostatis }\end{array}$ \\
\hline 3 & Periode Pasut & $\begin{array}{l}\text { - Ketersediaan cahaya } \\
\text { - Kekeringan jika lerekspos pada saing hari }\end{array}$ \\
\hline 4 & Arus dan Gelombang & - Distribusi spcsics - Proses reproduksi \\
\hline 5 & Salinitas & - Stress terhadap tekanan osmotik \\
\hline 6 & Suhu & $\begin{array}{l}\text { - Suhu optimum untuk fotosintesis dan } \\
\text { pertumbuhan } \\
\text { - Distribusi berbeda untuk lintang }\end{array}$ \\
\hline 7 & Anthropogems & $\begin{array}{l}\text { - Eutrofikasi } \\
\text { - Sedimentasi } \\
\text { - Boat anchoring } \\
\text { - Dredging } \\
\text { - Polusi perairan }\end{array}$ \\
\hline
\end{tabular}

Sumber: Azkab 1988

\section{REHABILITASI LAMUN}

Lamun memegang peranan penting pada fungsi-fungsi biologis dan fiisik dari lingkungan pantai pesisir (Thayer et al. 1975; Thorhaug 1986). Walaupun demikian, meningkatnya aktivitas pembangunan di lingkungan pesisir akan berdampak terhadap produktivitas sumberdaya pesisir. Lamun, sekali rusak atau terganggu, tidak akan baik kembali seperti pada tan am an di darat (Fonseca, 1987). Karena padang lamun mungkin akan rusak akibat aktivitas pembangunan di daerah pantai, metode-metode harus dibuat untuk mengurangi dampak pembangunan dan penggunaan lamun untukmenstabilkan subtrat yang dapat berguna pada navigasi pelayaran misalnya. Diperlukan tindakan rehabilitasi sumber daya hayati lamun pada spesies Halophila spinulosa karena rendahnya kerapatan spesies dan adanya aktivitas manusia yang merusak komunitas lamun. Tindakan rehabilitasi berupa pembentukan kelembagaan yang mengarah pada strategi pengelolaan komunitas lamun secara tepat dan terpadu dengan penekanan pada aspek social masyarakat, pemberian penyuluhan kepada masyarakat serta penanaman spesies lamun Halophila spinulosa. Selain itu diperkukan upaya preservasi sumberdaya hayati lamun pada spesies Cymodocea rotundata karena tingginya kerapatan spesies dengan cara pengawetan spesies lamun Cymodocea rotundata dan membiarkan populasinya tetap seimbang menurut proses alami di habitatnya dan menjaga keutuhannya agar tetap dalam keadaan asli.

Merujuk pada kenyataan bahwa padang lamun mendapat tekanan gangguan utama dari aktivitas manusia maka untuk rehabilitasinya dapat dilaksanakan melalui dua pendekatan: yakni: 1) rehabilitasi lunak (soft rehabilitation), dan 2) rehabilitasi keras (hard rehabilitation). (www.krak.com/ query? $\mathrm{stq}=0 \&$ what $=$ wrel...lamun $\% 2 \mathrm{~F}$ ).

\subsection{Rehabilitasi Lunak}

Rehabilitasi lunak berkenan dengan penanggulangan akar masalah, dengan asumsi jika akar masalah dapat 
diatasi, maka alam akan mempunyai kesempatan untuk merehabilitasi dirinya sendiri secara alami. Rehabilitasi lunak lebih menekankan pada pengendalian perilaku manusia.

Rehabilitasi lunak bisa mencakup hal-hal sebagai berikut:

a) Kebijakan dan strategi pengelolaan. Dalam pengelolaan lingkungan diperlukan kebijakan dan strategi yang jelas untuk menjadi acuan pelaksanaan oleh para pemangku kepentingan (stake holders).

b) Penyadaran masyarakat (Public awareness). Penyadaran masyarakat dapat dilaksanakan dengan berbagai pendekatan seperti:

- Kampanye penyadaran lewat media elektronik (televisi, radio), ataupun lewat media cetak (koran, majalah, dll)

- Penyebaran berbagai materi kampanye seperti: poster, sticker, flyer, booklet, dan lain-lain

- Pengikut-sertaan tokoh masyarakat (seperti pejabat pemerintah, tokoh agama, tokoh wanita, seniman, dll) dalam penyebarluasan bahan penyadaran.

c) Pendidikan. Pendidikan mengenai lingkungan termasuk pentingnya melestarikan lingkungan padang lamun. Pendidikan dapat disampaikan lewat jalur pendidikan formal dan nonformal

d) Pengembangan riset. Riset diperlukan untuk mendapatkan informasi yang akurat untuk mendasari pengambilan keputusan dalam pengelolaan lingkungan.

e) Mata pencaharian alternatif. Perlu dikembangkan berbagai kegiatan untuk mengembangkan mata pencaharian alternatif yang ramah lingkungan yang dapat meningkatkan kesejahteraan masyarakat. Masyarakat yang lebih sejahtera lebih mudah diajak untuk menghargai dan melindungi lingkungan. f) Pengikut sertaan masyarakat. Partisipasi masyarakat dalam berbagai kegiatan lingkungan dapat memberi motivasi yang lebih kuat dan lebih menjamin keberlanjutannya. Kegiatan bersih pantai dan pengelolaan sampah misalnya merupakan bagian dari kegiatan ini.

g) Pengembangan Daerah Pelindungan Padang Lamun (segrass sanctuary) berbasis masyarakat. Daerah Perlindungan Padang Lamun (DPPL) merupakan bank sumberdaya yang dapat lebih menjamin ketersediaan sumberdaya ikan dalam jangka panjang. DPPL berbasis masyrakat lebih menjamin keamanan dan keberlanjutan DPPL.

h) Peraturan perundangan. Pengembangan pengaturan perundangan perlu dikembangkan dan dilaksanakan dengan tidak meninggalkan kepentingan masyarakat luas. Keberadaan hukum adat, serta kebiasaan masyarakat lokal perlu dihargai dan dikembangkan.

i) Penegakan hukum secara konsisten. Segala peraturan perundangan tidak akan ada manfaatnya bila tidak dapat ditegakkan secara konsisten. Lembaga-lembaga yang terkait dengan penegakan hukum perlu diperkuat, termasuk lembaga-lembaga adat.

\subsection{Rehabilitasi Keras}

Rehabiltasi keras menyangkut kegiatan langsung perbaikan lingkungan di lapangan. Ini dapat dilaksanakan misalnya dengan rehabilitasi lingkungan atau dengan transplantasi lamun di lingkungan yang perlu direhabilitasi. Penanaman lamun yang dikenal dengan "transplantasi" merupakan salah satu cara untuk memperbaiki ataumengembalikan habitat yang telah mengalami kerusakan. Pertama dimulai oleh Addy tahun 1947 pada jenis Zostera marina, Fuss \& Kelly pada jenis Thallasia testudinum dan Halodule wrightii (Phillips, 1974), dan jenis 
Thallasia testudinum oleh Thorhaug (Thorhaug, 1974). Jenis lain yang sering digunakan dalam transplantasi khususnya di luar negeri adalah jenis-jenis Zostera marina, Halo du le wrightii, Thalassia testudinum, Syringodium filiforme, dan Ruppia maritima (Phillips, 1980). Sedangkan di Indonesia adalah jenis Cymodocea rotundata dan Thalassia hemprichii (Azkab, 1987, 1988).

\subsection{Metode Tranplantasi/Penanaman Lamun}

Penanaman lamun yang dikenal dengan "transplantasi" merupakan salah satu cara untuk memperbaiki atau mengembalikan habitat yang telah mengalami kerusakan. Cara ini telah banyak dilakukan oleh para ahli di luar negeri dengan metode dan jenis yang berbeda. Pertama dimulai oleh Addy tahun 1947 pada jenis Zostera marina, Fuss \& Kelly pada jenis Thallasia testudinum dan Halodule wrightii (Phillips, 1974), dan jenis Thallasia testudinum oleh Thorhaug (Thorhaug, 1974).

Menurut Azkab (1999), bahwa metode penanaman atau transplantasi yang pernah dilakukan oleh Addy, Burkho Dohemy, Kelly, Thorhaug \& Phillips (Phillips 1980) adalah: Metode pembibitan/pembenihan (Seed/ Seeding), Metode "sprig" dengan jangkar atau tanpa jangkar (Sprigs anchored and unanchored) Metode "plug" (Plug), (No. 1 adalah penanaman (planting), No.2 dan 3 adalah transplantasi (transplantation)

\subsubsection{Metode Seed/Seeding}

Biji biasanya dikoleksi dari buah yang tua atau diambil dari bibit yang tumbuh pada permukaan sedimen. Untuk memanennya, buah dipotong dari tangkainya dan dipecah maka kelihatan 4 atau lima biji. Biji dan benih segera ditanam atau ditaruh di lapangan atau laboratorium dan disiram dengan air laut yang mengalir (Thorhaug, 1974).

Menurut Mcmillan (1981) dan PHILLIPS (1960) ada 4 jenis dari 7 jenis yang telah didokumentasi untuk memproduksi biji atau benih yaitu Thalassia testudinum, Halodule wrightlii, Syringodium filiformedan Ruppia maritima. Tetapi hanya biji Thalassia dan Ruppia yang cukup secara kuantitatif untuk restorasi (Durako \& Moffler 1981; Lewis \& Phillips 1980; Phillips \& Lewis, 1983). Thalassia mempunyai biji yang berkecambah. McMillan (1981) telah mengoleksi biji yang berkecambah dari Halodule dan Syringodium dari pulau-pulau kecil di Florida, tetapi jumlahnya tidak mencukupi dalam skala besar. Biji Thalassia dengan skala luas dapat tersedia untuk daerah Selatan Florida (Lewis \& Phillips 1980).

Pembenihan secara langsung dengan benih Thalassia telah dilakukan oleh Thorhaug (1974). Kemudian penanaman langsung dari biji yang dikoleksi telah dilakukan dalam skala besar di Teluk Biscayne (Gaby Langley 1985) dan pulau-pulau kecil di Florida (Lewis et al. 1982), tetapi kurang begitu sukses. Untuk jenis Ruppia sampai saat ini belum ada laporan yang menggunakan biji untuk restorasi. Menurut Thorhaug (1974) bahwa sampai saat ini pengetahuan teknik untuk pembenihan masih sangat sedikit, sehingga penanaman dengan biji tidak direkomendasi untuk penanaman lamun. Hal ini juga berkaitan dengan biji yang kurang sukses untuk jenis lamun lain. Di samping itu, secara umum, biji atau benih dari jenis lamun lain sangat kecil dan mudah terbawa air, serta kecepatan perkecambahan sangat rendah.

\subsubsection{Metode Sprig anchored and unanchored}

Metode spirg yaitu pengambilan bibit tanaman dengan pisau/parang dan ditranspinatsai tanpa substratnya. Untuk penanaman dengan metode sprig dengan jangkar biasanya dilakukan pada arus dengan 1,5 knot (kira-kira $3 \mathrm{~km}$ per jam) atau pada daerah dengan gelombang akibat angin. Di Missisipi, Eleuterius (1974) menemukan bahwa dengan kontruksi balok dan besi yang 
digunakan untuk jangkar tidak berpengaruh pada transplantasi untuk jenis lamun Halodule wrightii dan Thallasia testudinum. Tetapi Phillips (1976) dengan jenis yang sama yang dilakukan di Alaska akan mati jika menggunakan logam sebagai jangkarnya. Sedangkan di Puget, Washington, untuk jenis Zostera marina tidak berpengaruh jika menggunakan besi atau logam sebagai jangkar.

Mengingat dengan menggunakan balok dan kawat akan meningkatkan biaya, maka disarankan menggunakan plastik bentuk kasa (net). Beberapa tanaman dapat tumbuh dengan cepat dengan menggunakan tehnik ini. Penanaman metode sprig tanpa jangkar telah banyak berhasil untuk jenis Zostera marina dan Halodule wrightii. Biasanya untuk jenis Zostera cukup dengan 3 atau 4 turion (shoot), sedangkan untuk jenis Halodule adalah 15-20 turion pada rimpang (rhizome) yang sama. Metode ini ditanam dengan menggali sebuah lubang kecil pada substrat (dalamnya kirakira $8 \mathrm{~cm}$ ), kemudian ditutup dengan substrat yang sama. Metode ini hanya dapat berhasil jika arus atau gelombang yang rendah.

\subsubsection{Metode Plug}

Metode plug yaitu pengambilan bibit tanaman dengan patok paralon dan tanaman dipindahkan dengan substratnya. Biasanya menggunakan paralon (PVC) dengan diameter $10 \mathrm{~cm}$ untuk jenis Halodule, sedangkan untuk Zostera, Thalassia dan Syringodium dengan diameter 15-20 cm. Metode plug dengan menekan ke tanaman masuk ke substratnya, kemudian ditransplantasi pada lobang yang sama pada kedalaman $15-20 \mathrm{~cm}$. Phillips et al. (1978) merekomendasikan bahwa metode plug untuk Zostera ditransplantasi pada kedalaman $45 \mathrm{~cm}$ atau lebih. Pada percobaan di pelabuhan St. Joe, Florida menunjukkan bahwa dengan jarak tanam $15 \mathrm{~cm}$ muncul rumpun yang padat, tetapi pada jarak $30 \mathrm{~cm}$ tidak ada tumbuhan yang padat.

Untuk menghindari kerusakan yang permanen dari padang lamun donor, maka pengambilan tanaman dengan plug jangan terlalu dekat satu dengan yang lain. Jarak satu sama lain bervariasi antara 0,5 sampai $1,0 \mathrm{~m}$ (Phillips et al. 1978; Van Breedveld 1975).

\subsubsection{Waktu Penanaman}

Secara umum, di luar negeri waktu yang baik untuk transplantasi adalah pada musim semi. Tetapi, transplantasi ini mungkin dapat dilakukan kapan saja untuk Teluk Meksiko, Selatan Beufort pantai Atlantik, Carolina Utara, dan pantai Pasifik mulai dari Washington sampai bagian selatan California, karena daerah-daerah tersebut bebas dari laut es pada musim dingin, walaupun waktu yang spesifik telah direkomendasikan dari studi sebelumnya (Churcill et al. 1978; Phillips, 1976; Phillips et al. 1978; Thorhaug 1974,1976). Sedangkan di bagian utara Beufort pantai Atlantik dan Alaska di pantai Pasifik, dimana ada laut es pada musim dingin, maka transplantasi dilakukan jika es mencair dan tanaman vegetatifnya mulia tumbuh. Tabel 3 menunjukkan daftar rekomendasi waktu transplantasi untuk setiap jenis dan lokasi. Untuk perairan Indonesia, khsususnya di gugus Pulau Pari transplantasi dapat dilakukan sepanjang tahun. Untuk jenis Thalassiadan Cymodocea yang terbaik adalah pada Musim Barat (Azkab 1987, 1988). Pada Tabel 4 menunjukkan persentase tumbuh dari masing-masing jenis lamun pada beberapa lokasi.

\subsubsection{Kondisi Lingkungan}

Pada penanaman dan transplantasi lamun beberapa faktor lingkungan yang perlu diperhatikan yaitu: kedalaman, cahaya, temperatur, salinitas, nutrien, arus dan gelombang (Phillips, 1980).

\section{a. Kedalaman}

Distribusi kedalaman lamun tergantung dari hubungan beberapa faktor yaitu; gelombang, arus, substrat, turbiditas dan 
penetrasi cahaya. Pada daerah subtropis (temperate) Zostera tumbuh mulai surut terendah sampai kedalaman kira-kira $10 \mathrm{~m}$ (Phillips, 1974). Cottam \& Munro, (1954) mengamati Zostera dapat tumbuh sampai kedalaman $30 \mathrm{~m}$ jika perairannya terang/bersih. Pada daerah tropik Halodule tumbuh mulai dari daerah pasang-surut sampai pada kedalaman $14 \mathrm{~m}$, sedangkan Thalassia dan Syringodium tumbuh dari surut terendah sampai kedalaman 10-20 m. Di Bahama, Thalassia dapat tumbuh sampai kedalaman $35 \mathrm{~m}$ pada perairan yang terang/bersih (Phillips, 1960). Sedangkan pada perairan yang keruh (turbiditas tinggi), Iamun hanya dapat tumbuh di bawah $1 \mathrm{~m}$ (Thayer et al, 1975).

\section{b. Cahaya}

Backman \& Barilotti (1976) mendemonstrasikan bahwa pembungaan dan kerapatan dari Zostera marina di goba sebelah selatan California ada hubungannya dengan intensitas dan penetrasi cahaya oleh kolom air. Dengan menutup tanaman (terpal) pada perairan dangkal akan menurunkan penyinaran sampai $63 \%$. Setelah 18 hari, kerapatan rata-rata yang dibawah terpal menurun dan seteIah 9 bulan kerapatan menurun sampai $5 \%$ lagi. Pembungaan juga menurun bagi tanaman yang ditutupi. Kenaikan kekeruhan dapat disebabkan oleh adanya pengerukan, buangan minyak. Di samping itu pada waktu yang lama, kerapatan tanaman dapat turun karena meningkatnya sedimen oleh erosi (Phillips, 1980).

\section{c. Temperatur}

Semua jenis lamun dapat tumbuh di bawah dan di atas pada tingkat temperatur yang normal (McMillan, 1978; Thayer et al. 1975). Zostera marina di sebelah utara dan selatan pantai Atlantik dan Pasifik dapat tumbuh dan toleran dengan temperatur yang tinggi dan rendah. Di Alaska pada daerah pasang-surut di tern ukan Zostera marina yang memperlihatkan kenaikan fotosintesa pada temperatur $35^{\circ} \mathrm{C}$. Sedangkan di bawah daerah pasang-surut, fotosintesa menurun pada $30^{\circ} \mathrm{C}$. Lebih lanjut Zieman (1975) melaporkan bahwa fotosintesa pada lhalassia menurun jika dibawah atau di atas dari $28-30^{\circ} \mathrm{C}$. Sedangkan pada penelitian Thqrhaug \& Sterns (1972) pada temperatur yang tinggi, Thalassia dapat berbung a tetapi tidak berbuah. Di samping itu akibat temperatur yang tinggi akan mengakibatkan banyaknya daun yang hilang dan akan menaikkan temperatur sedimen Kenaikan temperatur sedimen akan membuat tanaman mati (Wood \& Zieman, 1969).

Tabel 3. Waktu penanaman menurut jenis dan lokasi

\begin{tabular}{|c|c|c|}
\hline Jenis & Lokasi & Waktu \\
\hline \multirow[t]{2}{*}{ Zostero marina } & $\begin{array}{l}\text { pantai Alaska dan Alantaik utara, } \\
\text { Carolina Utara }\end{array}$ & Maret atau Mei sampai akhir Juli \\
\hline & $\begin{array}{l}\text { Beufort. Carolina Ulara, bagian } \\
\text { selatan pantai Atlantik }\end{array}$ & $\begin{array}{l}\text { akhir September sampai awal } \\
\text { December }\end{array}$ \\
\hline \multirow[t]{2}{*}{ Halodule wrightii } & Washington sampai selatan & Januari sama Mei (tetapi dapat \\
\hline & $\begin{array}{l}\text { Calofornia, pantai Pas.lik } \\
\text { pantai Teluk, pantai Atlantik, selatan } \\
\text { tanjung Canaveral. Florida }\end{array}$ & $\begin{array}{l}\text { sepanjang tahun setiap saat } \\
\text { sepanjang tahun }\end{array}$ \\
\hline Thalassia & pantai Teluk. pantai Atlantik, selatan & plug: Desember-April, seeding, \\
\hline Tetudinum & Tanjung Canaveral, Florida & untuk Thalasia Agustus \\
\hline $\begin{array}{l}\text { Syrigodiurn } \\
\text { filiforme }\end{array}$ & & $\begin{array}{l}\text { November, yang diproduksi di } \\
\text { lapangan }\end{array}$ \\
\hline $\begin{array}{l}\text { Cymodocea rotundata, } \\
\text { Thalassia hemprichii }\end{array}$ & $\begin{array}{l}\text { ratatan terumbu Pulau Pan } \\
\text { Kepulauan Senbu, Indonesia }\end{array}$ & setiap saat sepanjang tahun \\
\hline
\end{tabular}


Tabel 4. Persentase tumbuh dari masing-masing jenis dengan metode yang berbeda

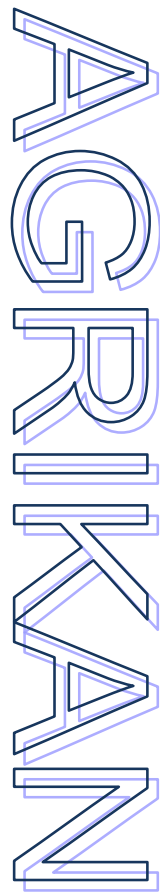

\begin{tabular}{llll} 
Jenis & Lokasi & Metode & Persentase (\%) \\
\hline Thalassia testudinurn & Biscaync Bay & Sprig & $90(1)$ \\
& North Biscaync Bay & Seed & $84(2)$ \\
& Turkey Point & Seed & $80(2)$ \\
Halodule wrightii & Nort Biscayne Bay & Sprig & $54(2)$ \\
& Jamaika & Plug & $63(1)$ \\
& Lake Surprise & Sprig & $100(2)$ \\
Zostcro marina & Whidbey Island & Anchor & $40(3)$ \\
Cymoroceo rotundata & Pulau Pari & PIIIR & $38(4)$ \\
& & Sprig & $43(4)$ \\
Thalassia hemprichii & Pulau Pari & Plug & $78(5)$ \\
& & Sprig & $77(5)$ \\
\hline
\end{tabular}

Sumber: Phillips 1980, Azkab 1987, 1988

Keterangan : (1) Thorhaug (1974), (2) Thorhaug (1986), (3) Phillips (1974), (4) Azkab (1987), (5) Azkab (1988).

\section{d. Salinitas}

Perubahan salinitas kurang berpengaruh seperti pada perubahan temperatur. Zostera marina dapat tumbuh pada salinitas $10-30 \%$ dan Thalassia pada salinitas $20-35 \%$ (Phillips 1960, 1972). Sedangkan Halodule pada daerah tropik dapat tumbuh pada salinitas 3,5-60\%, sehingga jenis ini Iebih tinggi resistennya pada salinitas yang tinggi dibandingkan dengan jenisjenis lamun lainnya (McMillan \& Moseley, 1967).

e. Nutrien

Nutrien di kolom air bukan merupakan faktor pembatas untuk lamun. Nutrien umumnya ada pada sedimen, dan adanya logam berat pada sedimen tidak mempunyai efek pada lamun.

Padang lamun sangat penting dalam siklus nutrien. Nitrogen, Carbon, Sulfur dan nutrien lain akan dikonversi kedalam bentuk yang berguna bagi biota lainnya. Nutrien ini akan diserap oleh tanaman melalui akar dan akan dikeluarkan kedalam massa air. Daun Zostera marina dapat mengabsor fosfat, tetapi umumnya melalui akar baru ke daun dan masuk ke kolom air (McRoy \& Barsdate (1970).

Serasah juga(detritus) lamun juga sangat penting dalam siklus nitrien. Serasah dari daun akan dikumpulkan di sedimen pada padang lamun, tetapi mungkin Baja dapat keluar dari padang lamun tersebut. Menurut Fenchel (1977) yang sangat berperan pada siklus nutrien adalah mikroba dekomposisi (bakteri).

\section{f. Arus dan Gelombang}

Churchill et al. ( 1978) melaporkan bahwa dengan arus pasang-surut 1,5 $\mathrm{km} / \mathrm{jam}$ akan menghanyutkan semua transplantasi metode sprig dari Zostera marina dalam tempo 3 bulan di Teluk Great South, New York, dan dengan metode plug hanya memerlukan waktu 2 minggu pada arus pasang-surut yang berkekuatan 2,4 $\mathrm{km} / \mathrm{jam}$. Sedangkan dengan gelombang yang kuat dan gerakan air akibat perahu akan berpengaruh terhadap keberadaan dan pertumbuhan dari pembenihan Thalassia (Thorhaug, 1976).

\section{PENUTUP}

Sebagai sumber daya pesisir, ekosistem padang lamun memiliki multi fungsi untuk menunjang sistem kehidupan dan berperan penting dalam dinamika pesisir dan laut, terutama perikanan pantai sehingga pemeliharaan dan rehabilitasi ekosistem lamun merupakan salah satu alasan untuk tetap mempertahankan keberadaan ekosistem tersebut. Ekosistem lamun sangat terkait dengan ekosistem di dalam wilayah pesisir seperti mangrove, terumbu karang, estauria dan ekosistem 
lainya dalam menunjang keberadaan biota terutama pada perikanan serta beberapa aspek lain seperti fungsi fisik dan sosial-ekonomi. Hal ini menunjukkan keberadaan ekosistem lamun adalah tidak berdiri sendiri, tetapi terkait dengan ekosistem sekitarnya, bahkansangat dipengaruhi aktifitas darat. Namun, akhir-akhir ini kondisi padang lamun semakin menyusut oleh adanya kerusakan yang disebabkan oleh aktivitas manusia.
Sebagai upaya konservasi dan kelestariannya dalam rangka tetap mempertahankan lingkungan dan penggunaan yang berkelanjutan, maka dikembangkan pendekatan terpadu yang melibatkan berbagai pihak untuk perlu untuk membuat solusi tepat dalam mempertahankan fungsi ekologis dari ekosistem yaitu pengelolaan pesisir secara terpadu atau Integrated Coastal Management (ICM).

\section{DAFTAR PUSTAKA}

Aswandy, I. 2003. Asosiasi Fauna Krustasea dengan Potongan-Potongan Lamun di Laut Dalam. Jurnal Oseana Vol XXVIII, No 4. ISSN 0216-1877.

Azkab, M.H. 1987. Percobaan transplantasi lamun, Cy modocea rot undat a Ehrenb.\&Hempri.ex Aschers di rataan terumbu Pulau Pari, Kepulauan Seribu. Kongres Nasional Biologi VIII, Purwokerto 8-10 Oktober 1987, 20 h.

Azkab, M.H. 1988. Transplantasi lamun, Thalassia hemprichli(Ehrenb.)Aschers di rataan terumbu Pulau Pari, Kepulauan Seribu. Dalam: Teluk Jakarta; biologi, budidaya, oseanografi, geol ogi dan kondisi perairan ( M. K. Moosa, D. P. Praseno dan Sukarno, eds.). Puslitbang Oseanologi-LIPI, Jakarta, 105-111.

Azkab, M.H.1988. Pertumbuhan dan produksi lamun, Enhalus acoroides di rataan terumbu di Pari Pulau Seribu.Dalam: P3O-LIPI, Teluk Jakarta: Biologi,Budidaya, Oseanografi,Geologi dan Perairan. Balai Penelitian Biologi Laut, Pusat Penelitian dan Pengembangan Oseanologi-LIPI, Jakarta.

Azkab, M.H.1999. Kecepatan tumbuh dan produksi lamun dari Teluk Kuta, Lombok.Dalam:P3O-LIPI, Dinamika komunitas biologis pada ekosistem lamun di Pulau Lombok, Balitbang Biologi Laut, PustlibangBiologi Laut-LIPI, Jakarta.

Azkab, M. H. 1999. Pedoman Inventarisasi Lamun. Jurnal Oseana, Volume XXIV, Nomor 1, 1999 : 1- 16 ISSN 0216-1877.

Barber, B.J.1985. Effects of elevated temperature on seasonal in situ leaf productivity of Thalassia testudinum banks ex konig and Syringodium fliforme kutzing. Aquatic Botany 22:61-69.

Bengen,D.G. 2001. Sinopsis ekosistem dan sumberdaya alam pesisir. Pusat Kajian Sumberdaya Pesisir dan Lautan, Instititut Pertanian Bogor.

ChurchilL, C.A., A.E. COK and M.1. RINER 1978. Stabilization of subtidal sediments by the transplantation on the seagrass Zostera marina. Rept. No.NYSSGJP-RS-78-15, New York, 25 p.

Cottam, C. and A.D. Munro 1954. Eel-grass status and environmental relations. J. Wild.Manag. 8(4): 449-460. 


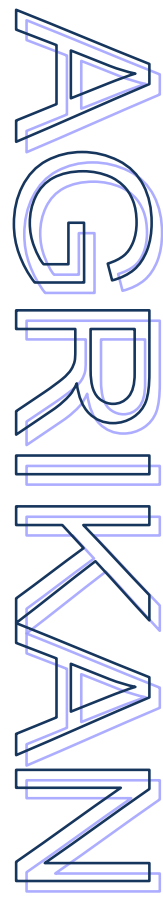

Den Hartog, C. (1970). "Sea grasses of the world" North Holland Publishing c o., Amsterdam, London pp. 272 .

Darovec, J.E., 1.M. Carlton, T.R. Pulver, M.D. Moffler, G.B. Smith, W.K. Whitfield, S.A.

Willis, K.A. Steidinger and E.A. Joyce 1975. Techniques for coastal restoration and fishery enhancement in Florida. Nat.Kesour.Bur.Mar.Re.s.St. 15: 10-30.

Durak;O, M.J. and M.D. Moh-ler 1981. Variation in Thalassia testudinum seedling growth related to geographic origin. In: Proc.8th Ann.Conf. Wetlands Restoration and Creation. (R.H. Stovall, ed.). Hillsbrough Community Colege, Tampa, Florida, p.132-154.

Eleuterius, L.N. 1974. A study of plant establishment on spoil areas in Missisippi sound and adjacent waters. Report No. 74, US Army. 47p.

Fenchel, T 1977. Aspects of the decomposition of seagrasses. Nat.Sci. Found., Leiden, 18p.

Fonseca, M.S. 1987. The management of seagrass system. Trop. Coast. Area. Manag. 2(2): 5-10.

Fonseca, M.S., G.W. thayer and W.J. KenworthY. 1987. The use ecological data in the implimentation and management of seagrass restoration. In: Proc. of the Symp. on Subtropical-Tropical Seagrass of the Souteastern United Stated (M.J Durako, R. C. Phillips and R.R. Lewis, eds.). Fla.Mar.Res.Publ. 42: $1-209$.

Gary, R. and S. Langley 1985. Seagrass mitigation in Biscayne Bay, Florida. In: Coastal Zone (0.T. Magoon, ed.). ASCE, New York, p 904-919.

Ginsburg, R. and H.A. Lowestan 1958. The influence of marine bottom communities on the depositional environments of sediment. J. Geol. 66 (3): 310-318.

Hartog, C.den.1970. Seagrass of the world. North-Holland Publ.Co.,Amsterdam Jannasch, H. W., K. Eimhjellen, CO. WIRSEN and A f Armanfarmian, 1971.

Jannasch, H. W. and CO. WIRSEN, 1973. Deep-sea microorganisms: In situ response to nutrient enrichment. Science 180:641-643.

Helferich (eds.) Seagrass ecosystem : A scientific perspective. Mar. Sci. Vol. 4 Marcel Dekker Inc. New York: 357 pp.

Kiswara W. 1999. Perkembangan Penelitian Ekosistem Padang Lamun di Indonesia. Disampaikan pada Seminar Tentang Oseanografi Dalam Rangka Penghargaan kepada Prof. Dr. Apriliani Soegiarto, M.Sc, Puslitbang Oseanografi LIPI Jakarta 1999.

Lewis, R.R., R.C. Phillips, D.J. Adamek and J.C. Cato 1982. Final report, seagrass revegetation studies in Monroe County. Florida Oept. of Transportation. Thallahassac, Florida, 95p. 
McRoy, C.P. \& C. Helferich. (1977). "Sea Grass Ecosystem" Marcel Dekker Inc. New York \& Basel pp. 314.

Phillips dan H.P.Calumpong. 1983. Sea Grass from the Philippines. Smithsonian Cont. Mar. Sci. 21. Smithsonian Inst. Press, Washington.

Poiner, I.R. \& G. Roberts,.(1986) "A brief review of seagrass studies in Australia. Proc.National conference and Coastal Management. 2, 243-248.

Thayer, G.W., S.M. Adams and M.W. La Croix, 1975. Structural and functional aspects of a recently established Zostera marina community. In : L.E. CRONIN (ED.).

Thomlinson, P.B. 1974. Vegetative morphology and meristem dependence - the Foundation of Productivity in seagrass. Aquaculture 4: 107-130.

Thorhaug, A. and C.B. Austin 1976. Restoration of seagrass with economic analysis. Env. Conserv. 3 (4) : 259-257.

Wake, J. (1975). A study of habitat requirements and feeding biology of dugong, Dugong dugong (Muller). Unpublished BSc Thesis, Departmen of Marine Science, James Cook University of North Queensland, Townsville pp. 6 - 7.

Wood, E. J. F. , W.E. Odum and J. C. Zieman. (1969), Influence of the seagrasses on the productivity of coastal lagoons, laguna Costeras. Un Simposio Mem. Simp. Intern. U.N.A.M. - UNESCO, Mexico,D.F., Nov., 1967. pp 495 502 .

Wolff, T. 1980. Animals associated with seagrass in the deep sea. In: Handbook of seagrass biology (R.C. Phillips and P.C. McRoy, eds.). Garland STPM Press, New York, p. 199-2.24.

Zieman, J.C. (1975). "Tropical seagrass ecosystems and pollution" In Tropical Marine pollution. E.J. Ferguson wood \& R.E. Johannes (ed.). Elsevier Sci. Publsh. Co. Amsterdam pp. 63-73. 